\title{
Investigation on Dynamics of Sediment and Water Flow in a Sand Trap
}

\author{
M. R. Mustafa \\ Department of Civil Engineering \\ Universiti Teknologi Petronas \\ 31750 Tronoh, Perak, Malaysia
}

\section{R. B. Rezaur}

Water Resources Engineer

Golder Associates Ltd.

Calgary T2A 7W5, Alberta, Canada

\author{
A. R. Tariq \\ Centre of Excellence in Water Resources \\ Engineering,University of Engineering and \\ Technology, Lahore, Pakistan
}

\author{
M. Javed \\ Hydraulics Division, \\ Pakistan Engineering Services \\ Lahore, Pakistan
}

\begin{abstract}
Sediment and flow dynamics in a sand trap of Golen Gol hydropower project in Pakistan was evaluated using a Computational Fluid Dynamics (CFD) model. Sediment Simulation in Intakes with Multi Block Options (SSIIM) CFD model was used to simulate the sediment and flow behavior in the sand trap. Numerical simulation results demonstrated that the horizontal and vertical component of velocities at any region of settling basin was less than the designed critical flow velocity of the sand trap. The design with respect to dimensions and proportioning of the sand trap were found appropriate for inducing low flow velocities throughout the settling basin of the sand trap supporting the deposition of sediments. The results obtained from simulation further presented the $100 \%$ removal of the desired sediments (particle size class $\geq 0.205 \mathrm{~mm}$ diameter) could be achieved in the sand trap. All this verify the design of sand trap is in accordance with the desired designed sediment removal efficiency of the sand trap.
\end{abstract}

Keywords-discharge; hydropower; sand trap; sediment, simulation

\section{INTRODUCTION}

River flows usually carry large amount of sediments of varying gradation. However, large sediment loads entering into diverted water (irrigation, hydropower) are undesirable. Sand traps are one of the most effective devices used to remove sediment particles from flowing water. In sand trap silt laden water enters at one end and clear water exits through the other end depositing a significant proportion of sediment in the sand trap. A sand trap reduces the velocity of flow through expansion of its cross section along the length of the silt trap [1]. The widening of cross section reduces flow velocities, shear stress and turbulence. As a result, suspended and bed materials loose their mobility and therefore they deposit. The sediment that deposits in the silt trap is removed periodically, either mechanically or by flushing.

However, the design of sand trap is based on empirical equations. Therefore, it is necessary to evaluate the performance of the selected design either by physical model study or by numerical modeling or both. Physical modeling is often expensive and time consuming. On the other hand numerical model study is relatively cheap and various alternatives can be evaluated within a short time by varying the layout of the sand trap and examining the flow and sediment dynamics in the sand trap. However, accurate 3D computational flow models are required to obtain acceptable results. Three-dimensional numerical studies performed for simulating water and sediment flow in sand traps [2], sediment deposition in dam [3], and scouring around bridge piers [4] showed the usefulness of numerical modeling.

In this study the flow and sediment transport hydraulics in a sand trap designed for a hydropower station at Golen Gol, Pakistan, is evaluated using a 3D computational flow dynamics model SSIIM (Sediment Simulation in Intakes with Multi Block Options). The hydraulics of the diversion weir, diversion intake channel and under sluice associated with the sand trap was evaluated by Pakistan Engineering Services (PES) [5] through physical model study. However, the hydraulics of the sand trap was not evaluated.

The objectives of this study are (i) to evaluate sediment flow and water flow dynamics in a sand trap designed for Golen Gol hydropower station, and (ii) to evaluate sediment removal performance of the sand trap.

\section{METHODOLOGY}

\section{A. Study Area}

The Golen Gol hydropower station is located in Chitral, the northern district of North Western Frontier Province (NWFP) of Pakistan. The hydropower station is expected to generate $106 \mathrm{MW}$ of electricity from the flow of Golen Gol stream, which is a tributary to River Mastuj. A weir is constructed to divert the flow of Golen Gol stream into the sand trap, 
followed by head race channel. Layout of the weir, sand trap and head race channel is shown in Figure 1.

Golen Gol stream has step like steep gradient and the catchment area is characterized by steep and narrow valley. The valley height ranges between $1830 \mathrm{~m}$ to $2440 \mathrm{~m}$ and enclosed by mountain ranges of height varying between $4875 \mathrm{~m}$ to $5800 \mathrm{~m}$ which forms the catchment boundary. Since turbine blades are seriously damaged by sediment laden flow, particularly sediment sizes $\geq 0.2 \mathrm{~mm}$ diameter are harmful to turbine blades the sand trap facility for the hydropower station was designed to remove sediment of size $\geq 0.2 \mathrm{~mm}$.

\section{B. Numerical Simulation}

The sand trap facility for the Golen Gol hydropower station has three identical chambers (Figure 1). Because of the symmetry of the chambers only one chamber is evaluated in the numerical simulation. The physical and hydraulic parameters used in the design of the sand trap are given in Table 1.

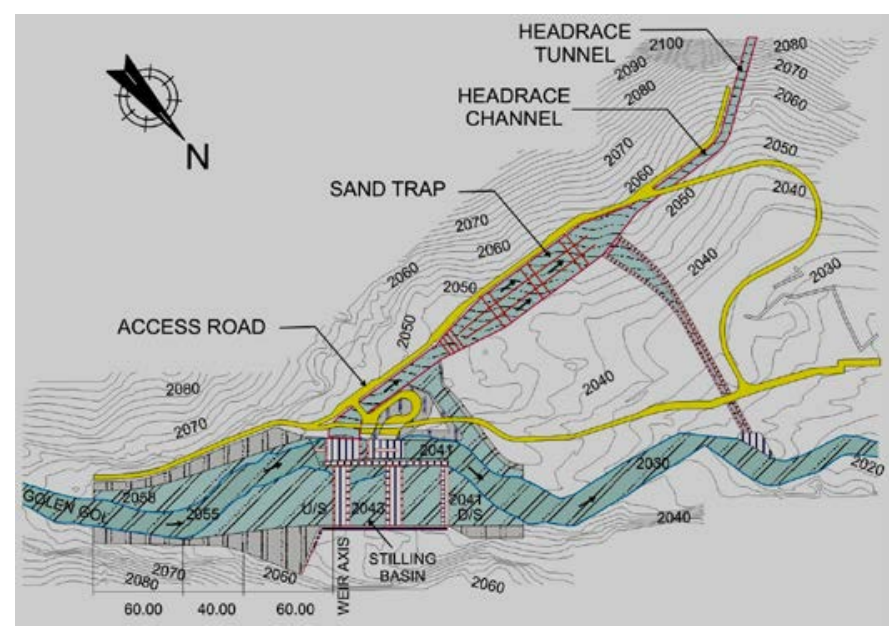

Figure 1. Layout details of the sand trap and headrace channel

TABLE 1.

DETAILS OF SAND TRAP PROPERTIES

\begin{tabular}{cc}
\hline Sand Trap Properties & Magnitude \\
\hline Physical parameters & 3 \\
No of chambers & $100 \mathrm{~m}$ \\
Length of settling basin & $12.5 \mathrm{~m}$ \\
Transition length at two ends & $6.5 \mathrm{~m}$ \\
Width of settling basin & $8 \mathrm{~m}$ \\
Depth of settling basin at entrance & $11 \mathrm{~m}$ \\
Depth of settling basin at exit & $3 \%$ \\
Bed slope of setting basin & $0.20 \mathrm{~mm}$ \\
Design settling particle size & \\
Hydraulic properties & $10 \mathrm{~m}^{3} / \mathrm{s}$ \\
Design discharge per chamber & $2 \mathrm{~m} / \mathrm{s}$ \\
Flushing discharge & $8 \mathrm{~m}^{3} / \mathrm{s}$ \\
Outlet discharge & $0.2 \mathrm{~m} / \mathrm{s}$ \\
Designed mean flow velocity & $0.2790 \mathrm{~kg} / \mathrm{s}$ \\
\hline
\end{tabular}

The incoming total sediment load $(0.2790 \mathrm{~kg} / \mathrm{s})$ to the sand trap listed in TABLE 1 was obtained from sediment rating curve derived from suspended sediment and water discharge measurement data available [5] on two locations, Babuka bridge on Golen Gol stream and Mastuj bridge on an adjacent river, River Mustuj. The suspended sediment loads obtained from the rating curve was $0.2426 \mathrm{~kg} / \mathrm{s}$. Assuming bed load to be $15 \%$ of the suspend sediment load the bed load was estimated to be $0.0364 \mathrm{~kg} / \mathrm{s}$. Thus the total incoming sediment load to the sand trap was estimated to be $(0.2426+0.0364)$ $=0.2790 \mathrm{~kg} / \mathrm{s}$.

Furthermore, study on grain size distribution characteristics of suspended and bed material samples collected [5] from Golan Gol stream showed that mainly five size classes of sediment dominated the particle size distribution. These were $0.059 \mathrm{~mm}, 0.108 \mathrm{~mm}, 0.157 \mathrm{~mm}$, $0.205 \mathrm{~mm}$ and $>0.205 \mathrm{~mm}$ size class. It was also found that each of the first four size classes of particles contributed each about $10 \%$ of the total weight, whereas size class $>0.205 \mathrm{~mm}$ contributed about $60 \%$ of the total weight. Therefore, in numerical simulation $10 \%(0.0279 \mathrm{~kg} / \mathrm{s})$ of the total sediment load $(0.2790 \mathrm{~kg} / \mathrm{s})$ was assigned to each of the first four size classes and the rest $60 \%(0.1674 \mathrm{~kg} / \mathrm{s})$ of the total sediment load was assigned to $>0.205 \mathrm{~mm}$ diameter size class. The critical mean velocity of flow and settling velocity of particles for different size classes was computed using Rouse diagram. The critical mean velocity of flow was found to be $0.2 \mathrm{~m} / \mathrm{s}$ based on the largest sediment size $(0.2 \mathrm{~mm})$.

Simulation of flow dynamics and sediment transport hydraulics was carried out using SSIIM (Sediment Simulation in Intakes with Multi Block Options) 3D modeling software [6]. For the numerical simulation the sand trap was discritized into cells with 100 vertical, 8 transverse, and 8 longitudinal grids. The cell configuration is shown in Figure 2. SSIIM uses the finite volume concept and solves the transient Reynold's averaged Navier-Stokes equations in threedimension to compute water flows. To compute the sediment movement it solves the convection-diffusion equation and uses the $k-\varepsilon$ model for turbulent shear stress computation.
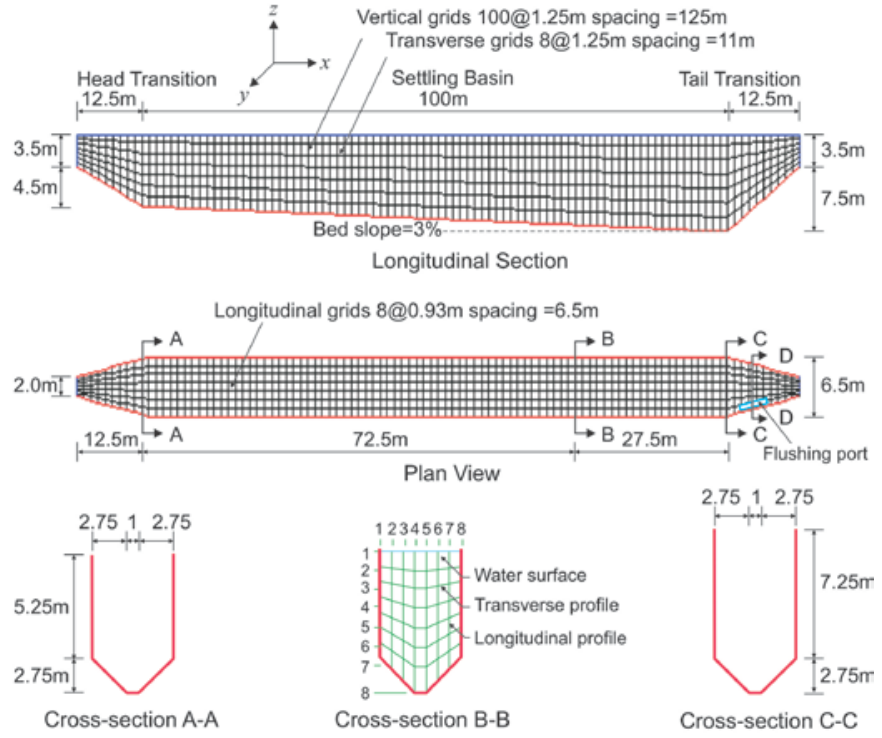

Figure 2. Plan, longitudinal and cross sectional view of the sand trap showing details of geometry and discritization for numerical simulation 


\section{Initial and Boundary Conditions:}

The boundary condition used for model simulation was, noflow across all solid boundaries (sand trap side walls, bottom surface) and top water surface of the sand trap. Flow was only allowed at the inlet, flush port and outlet of the sand trap. The initial conditions and other model parameters used in CFD simulation are given in TABLE 2.

Velocity vectors, flow velocity and sediment concentration profiles in the sand trap in lateral, longitudinal and vertical directions were evaluated to examine the performance of the sand trap. Finally the sediment removal efficiency of the sand trap was evaluated. Simulation was carried out until the flow or sediment concentration dynamics in the sand trap reached an equilibrium state. Equilibrium or stable condition was assumed to be established when no significant changes in flow velocities and sediment concentrations were found between few successive time steps. In this study equilibrium was achieved after 8110 seconds of flow simulation.

TABLE 2.

BOUNDARY CONDITIONS, INITIAL CONDITIONS AND MODEL PARAMETERS

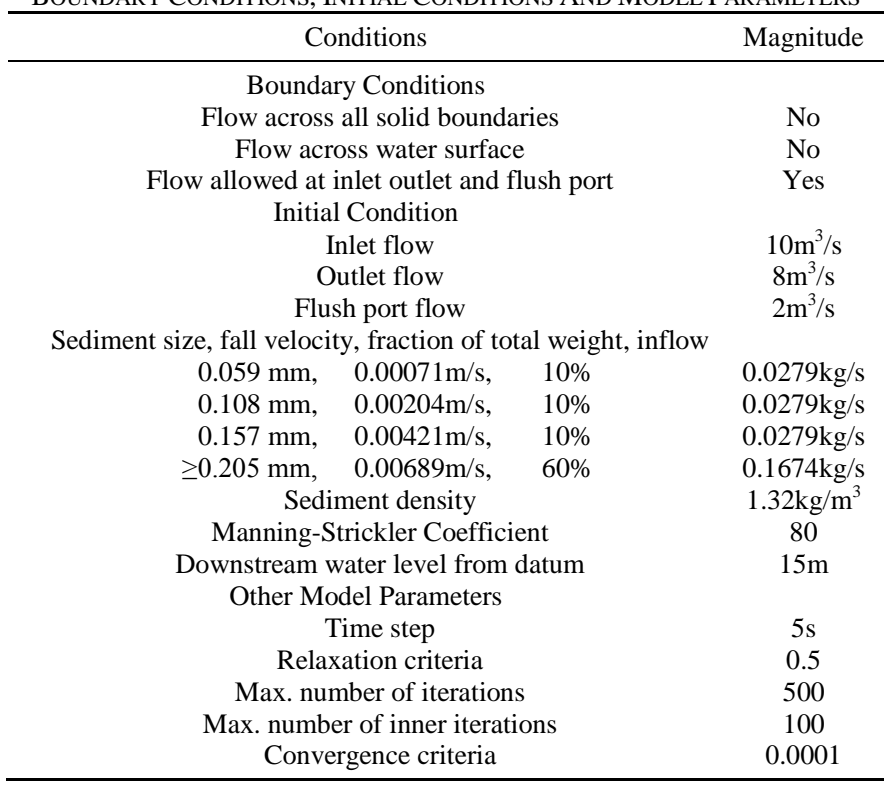

\section{RESULTS AND DISCUSSION}

\section{A. Results of Flow Velocity Vector Simulation}

The distribution of velocity vectors along the horizontal and vertical direction of the sand trap is shown in Figure 3 and Figure 4 respectively. The distribution of velocity vectors along the horizontal direction indicate that the magnitude of the velocity vectors at the entrance and exit of the sand trap are larger compared to the settling basin portion. The larger magnitude of velocity vectors at entrance and exit region of the sand trap suggests relatively higher flow velocity at these regions. In the mid region of the sand trap the velocity vectors are parallel to each other and of nearly similar magnitude suggesting uniform flow. The velocity vectors do not suggest any eddies or turbulence in the sand trap. Furthermore, the direction of the velocity vectors at the entrance is downwards indicating downward movement of water as it enters the sand trap while at the exit is upwards indicating outward movement of water.

(a)

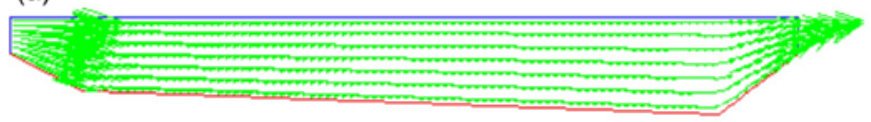

(b)

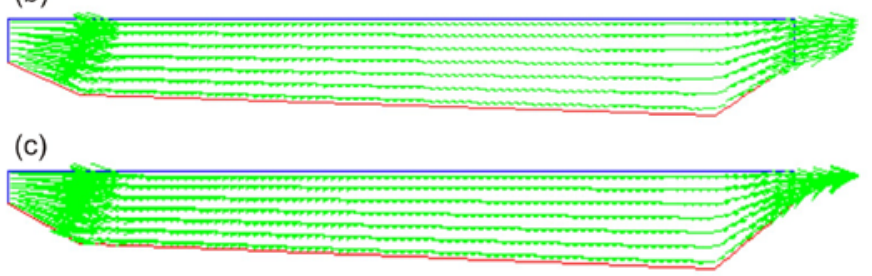

Figure 3. Longitudinal view of distribution of velocity vectors; (a) at longitudinal profile-2, $0.93 \mathrm{~m}$ form left bank, (b) at longitudinal profile-5 $3.72 \mathrm{~m}$ from left bank, (c) at longitudinal profile-8, $6.5 \mathrm{~m}$ from left bank

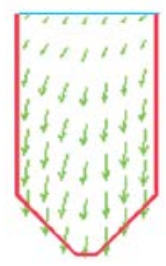

(a)

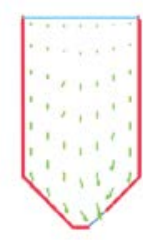

(b)

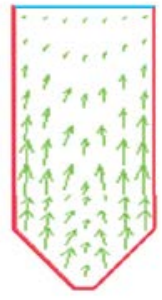

(c)
Cross-section A-A Cross-section D-D Cross-section C-C Figure 4. Cross-sectional view of distribution of velocity vectors; (a) at $12.5 \mathrm{~m}$ downstream of entrance, (b) at $85 \mathrm{~m}$ downstream of entrance, (c) at $112.5 \mathrm{~m}$ downstream of entrance

The cross sectional view of distribution of velocity vectors at the entrance, mid portion and at exit of the sand trap (Figure 4) also shows that velocity vectors at entrance and exit are larger compared to the middle portion of the sand trap. Furthermore the direction of flow as indicated by the velocity vectors suggests that at the entrance region movement of water is in the downward direction (Figure 4a), at the exit region the movement of water is in the upward direction (Figure 4c) and at the mid portion of the sand trap near the flushing port (Figure 4b) the direction of velocity vectors are towards the flushing port. These direction and magnitude of movement of water indicated by the velocity vectors are consistent with the designed expectations. The significance of flushing port and periodic flushing on the trapping performance of a sand trap was demonstrated in a study by Paulos [7] which showed that, when the flushing port was in use the sand removal efficiency of the sand trap was $63 \%$. When the flushing port was inoperative for about two months the trap efficiency was merely 6\%. The direction and magnitude of the velocity vectors observed near the flushing 
port (Figure 4b) suggests that the flushing port could perform satisfactory and that the location of the port is ideal.

\section{B. Results of Water Flow Simulation}

The longitudinal and cross-sectional views of distribution of simulated horizontal velocities in the sand trap are shown in Figure 5 and Figure 6 respectively. The longitudinal view of velocity contours (Figure 5) show that, the flow enters the sand trap with velocities ranging between 1.12-1.19 m/s and the velocities are reduced to about $0.29 \mathrm{~m} / \mathrm{s}$ within the $12.5 \mathrm{~m}$ length of the transition zone. Further downstream of the sand trap the velocities are reduced even further and ranges between $0.11-0.13 \mathrm{~m} / \mathrm{s}$ in the settling basin region.

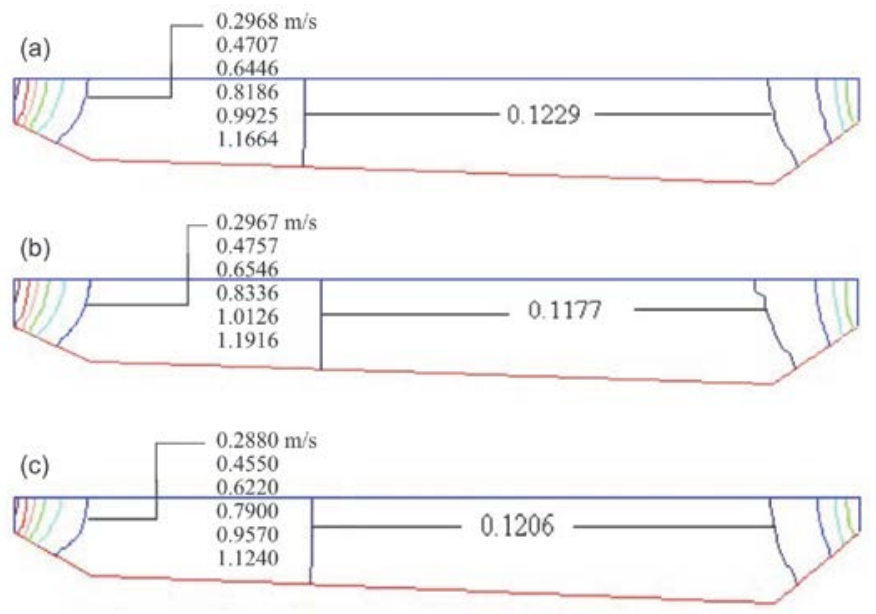

Figure 5. Longitudinal view of distribution of horizontal velocities; (a) at longitudinal Profile-2, $0.93 \mathrm{~m}$ form left bank, (b) at longitudinal Profile-5 $3.72 \mathrm{~m}$ from left bank, (c) at longitudinal Profile-8, $6.5 \mathrm{~m}$ from left bank

The cross-sectional view of the velocity distribution (Figure 6a) shows that the velocity at the entrance zone varies between $0.32 \mathrm{~m} / \mathrm{s}$ (near the free surface) to about $0.19 \mathrm{~m} / \mathrm{s}$ (near the bed level). The velocity at the exit zone (Figure 6c) varies between $0.62 \mathrm{~m} / \mathrm{s}$ (near the free surface) to about $0.51 \mathrm{~m} / \mathrm{s}$ (near the bed level). The velocity in the mid region of the sand trap (Figure 6b) are nearly uniform across the depth and varies only between $0.087 \mathrm{~m} / \mathrm{s}$ (near the free surface) to about $0.086 \mathrm{~m} / \mathrm{s}$ (near the bed level). Thus it appears that the relatively high velocities at the entrance and exit transition zones of the sand trap are ideal for cleaning purpose while the low velocities across the settling basin section of the sand trap are ideal for removal of sediments by deposition.

The cross-sectional view of distribution of vertical velocities in the sand trap is shown in Figure 7. The vertical velocity component at the entrance zone (Figure 7a) varies between $-0.02 \mathrm{~m} / \mathrm{s}$ (near the free surface) to about $-0.06 \mathrm{~m} / \mathrm{s}$ (near the bed level). The negative sign of velocities indicates that the flow is downwards at the entrance. The vertical velocity component at the exit zone (Figure 7c) varies between $0.04 \mathrm{~m} / \mathrm{s}$ (near the free surface) to about $0.25 \mathrm{~m} / \mathrm{s}$ (near the bed level). The vertical velocity component in the mid region of the sand trap (Figure $7 \mathrm{~b}$ ) varies between $0.002 \mathrm{~m} / \mathrm{s}$ (near the free surface) to about $-0.016 \mathrm{~m} / \mathrm{s}$ (near the bed level). The negative sign of velocities indicates that the flow is downwards at the entrance and settling basin zone, while at the exit zone the flow direction is upwards.

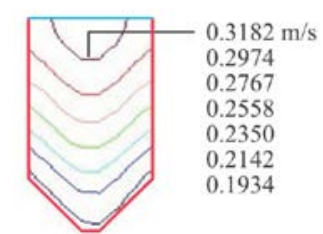

(a)

Cross-section A-A

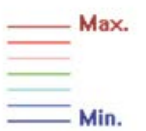

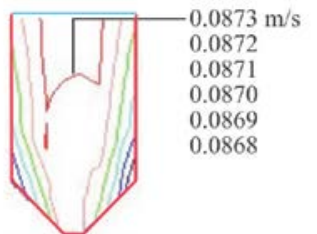

(b)

Cross-section B-B

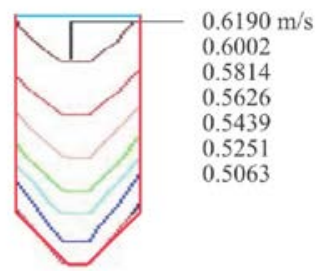

(c)
Cross-section C-C

Figure 6. Cross-sectional view of distribution of horizontal velocities; (a) at $12.5 \mathrm{~m}$ downstream of entrance, (b) at $85 \mathrm{~m}$ downstream of entrance, (c) at $112.5 \mathrm{~m}$ downstream of entrance

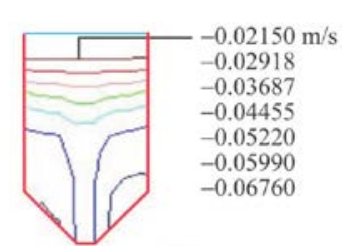

(a)

Cross-section A-A

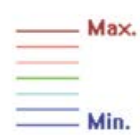

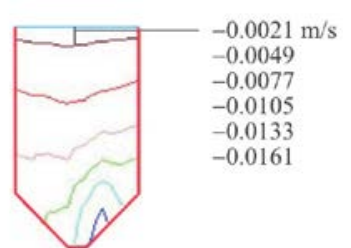

(b)
Cross-section B-B

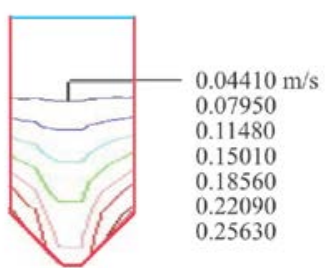

(c)

Cross-section C-C

Figure 7. Cross-sectional view of simulated vertical velocity profiles on (a) at $12.5 \mathrm{~m}$ downstream of entrance (b) at $85 \mathrm{~m}$ downstream of entrance (c) at $112.5 \mathrm{~m}$ downstream of entrance

The simulated horizontal (x-axis), and vertical (z-axis) component of velocities observed in Figures 5, 6 and 7 did not exceed the design critical flow velocity of $0.2 \mathrm{~m} / \mathrm{s}$ in any region of the settling basin of the sand trap. This suggests the dimensioning and proportioning of the sand trap are appropriate for inducing low flow velocities in the settling 
basin portion of the sand trap favorable for deposition of sediments.

\section{Results of Sediment Concentration Simulation}

The longitudinal view of distribution of sediment concentration in the sand trap along profile-3 for different particle size classes are shown in Figure 8.

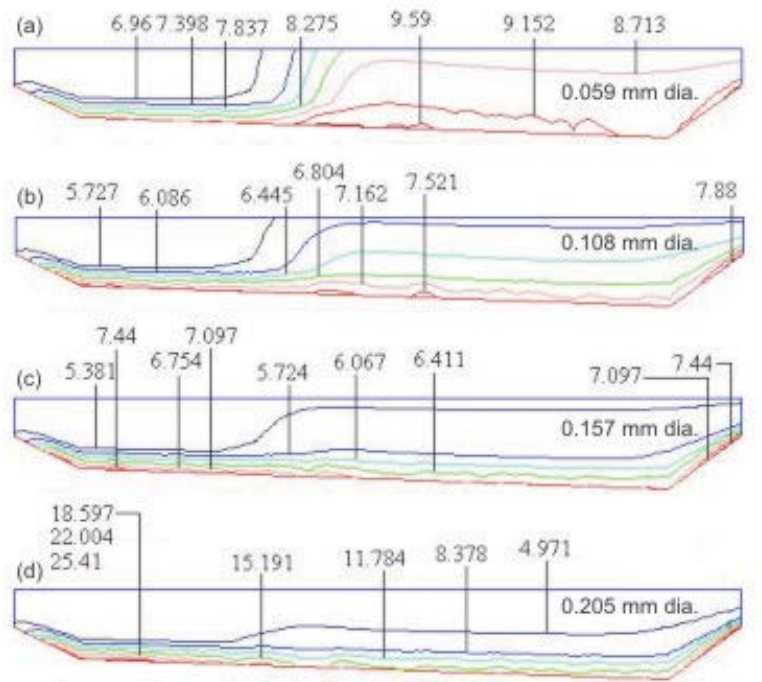

Figure 8. Longitudinal view of distribution of sediment concentration at profile-3 for (a) $0.059 \mathrm{~mm}$ diameter particle size, (b) $0.108 \mathrm{~mm}$ diameter particle size, (c) $0.157 \mathrm{~mm}$ diameter particle size, and (d) $0.205 \mathrm{~mm}$ particle size. All values are in $10^{6} \mathrm{ppm}$.

Figure 8 shows that relatively finer particles $(0.059 \mathrm{~mm}$ and $0.108 \mathrm{~mm}$ ) deposits mostly along the first $1 / 3$ segment (from left) of the sand trap whereas larger particles deposits along the entire length of the sand trap bed. Along the rest $2 / 3$ segment of the sand trap finer particles remains in suspension. Concentration of finer particles varied between $6.96 \times 10^{-6}$ $9.59 \times 10^{-6} \mathrm{ppm}$ and $5.73 \times 10^{-6}-7.88 \times 10^{-6} \mathrm{ppm}$ for $0.059 \mathrm{~mm}$ and $0.108 \mathrm{~mm}$ particle sizes respectively. Concentration of coarser particles varied between $5.38 \times 10^{-6}-7.44 \times 10^{-6} \mathrm{ppm}$ and $4.97 \times 10^{-6}-25.41 \times 10^{-6} \mathrm{ppm}$ for $0.157 \mathrm{~mm}$ and $0.205 \mathrm{~mm}$ particle sizes, respectively. Concentration of deposited sediments as is observed in Figure 8d shows that sediments with diameter $0.205 \mathrm{~mm}$ are deposited most (concentration near bed $25.41 \times 10^{-6} \mathrm{ppm}$ ). A few fractions of coarse particles ( $0.205 \mathrm{~mm})$ appear to be in suspended mode but very close to the bed level. The result from numerical simulation suggests that the sand trap could perform effectively for trapping particles $\geq 0.205 \mathrm{~mm}$ in diameter.

\section{Evaluation of Sand Trap Efficiency}

The statistics of dynamics of sediment in the sand trap in terms of percent of particle deposition (removal) for different size class is shown in Table 2.
TABLE 2.

STATISTICS OF SEDIMENT DYNAMICS IN THE SAND TRAP

\begin{tabular}{cccccccc}
\hline & \multicolumn{3}{c}{ Sediment load } & & \multicolumn{2}{c}{ Removal } \\
\cline { 1 - 1 } \cline { 8 - 9 } $\begin{array}{c}\text { Particle Size } \\
(\mathrm{mm})\end{array}$ & & $\begin{array}{c}\text { Inflow } \\
(\mathrm{kg} / \mathrm{s})\end{array}$ & $\begin{array}{c}\text { Outflow } \\
(\mathrm{kg} / \mathrm{s})\end{array}$ & $\begin{array}{c}\text { Suspended } \\
(\mathrm{kg} / \mathrm{s})\end{array}$ & & $\begin{array}{c}\text { (\%) of } \\
\text { Fraction }\end{array}$ & $\begin{array}{c}(\%) \text { of } \\
\text { Total }\end{array}$ \\
\hline 0.059 & & 0.0279 & 0.01784 & 0.000267 & & 36 & 3.6 \\
0.108 & & 0.0279 & 0.00767 & 0.000199 & & 73 & 7.3 \\
0.157 & & 0.0279 & 0.00127 & 0.000127 & & 95 & 9.5 \\
0.205 & & 0.0279 & 0.00005 & 0.000071 & & 100 & 10.0 \\
$>0.205$ & 0.1674 & 0.00000 & 0.000000 & & 100 & 60.0 \\
\hline
\end{tabular}

The simulated dynamics of sediment inflow and outflow rate (TABLE 2) show that, out of the total sediment load $(0.279$ $\mathrm{kg} / \mathrm{s}$ ) entering the sand trap the percentage of particles in different size classes, $0.059 \mathrm{~mm}, 0.108 \mathrm{~mm}, 0.157 \mathrm{~mm}$, $0.205 \mathrm{~mm}$ and $>0.205 \mathrm{~mm}$ removed were $3.6 \%, 7.3 \% 9.5 \%$, $10 \%$ and $60 \%$, respectively, resulting into an overall $90.4 \%$ removal of sediment for different size classes. However, within individual fraction of particle size entering the sand trap, the particle removal efficiency is $36 \%$ for $0.059 \mathrm{~mm}, 73 \%$ for $0.108 \mathrm{~mm}, 95 \%$ for $0.157 \mathrm{~mm}$ and $100 \%$ for $\geq 0.205 \mathrm{~mm}$.

The simulated results (Table 2 ) show that $100 \%$ removal for particle size class $\geq 0.205 \mathrm{~mm}$ diameter could be achieved in the sand trap. This is in accordance with the targeted designed sediment removal effectiveness of the sand trap. These results suggest that the dimensioning and proportioning of the sand trap are appropriate for the expected $100 \%$ deposition of sediment of size $\geq 0.2 \mathrm{~mm}$.

\section{CONCLUSIONS}

The study showed that the sand trap for Golen Gol hydropower station with dimension $100 \mathrm{~m} \times 7 \mathrm{~m} \times 8 \mathrm{~m}$, design discharge capacity of $10 \mathrm{~m}^{3} / \mathrm{s}$ and sediment load of $0.279 \mathrm{~kg} / \mathrm{s}$ can perform satisfactory. The numerical analyses showed that horizontal velocity in the range of $0.117 \mathrm{~m} / \mathrm{s}$ to $0.123 \mathrm{~m} / \mathrm{s}$ and vertical velocity in the range $-0.0168 \mathrm{~m} / \mathrm{s}$ to $-0.0161 \mathrm{~m} / \mathrm{s}$, ideal for deposition of particle size $\geq 0.2 \mathrm{~mm}$ could be attained in the settling basin region of the sand trap. These velocities are ideal for $100 \%$ deposition of sediment particle of size $\geq 0.2 \mathrm{~mm}$. Furthermore the sediment deposition for particle size classes $0.059,0.108,0.157 \mathrm{~mm}$ was found to be $36 \%$, $75 \%$ and $95 \%$ respectively. The overall removal efficiency was 90.4 percent.

\section{ACKNOWLEDGMENT}

The authors gratefully acknowledge the support given by Universiti Teknologi Petronas in presenting this study.

\section{REFERENCE}

[1] H. Lauterjung, and G. Schmidt, "Planning for Intake Structures. A Publication of GTZ-Postharvest project in: Deutsche Gesellschaft für Technische Zusammenarbeit (GTZ) GmbH. pp. 102, 1989.

[2] N.R.B. Olsen and M. Skoglund. "Three-dimensional numerical modeling of water and sediment flow in a sand trap" Journal of Hydraulic Research, IAHR. Vol. 32(6), pp. 833-844, 1994. 
[3] L. Yong-jun and W. Zhao-yin “3D Numerical Simulation for Water Flows and Sediment Deposition in Dam Areas of the Three Gorges Project” Journal of Hydrological Engineering. Vol. 135(9), pp. 755769, Sep. 2009.

[4] T. Esmaeili, A.A. Dehghani, A.R. Zahiri and K. Suzuki, "3D Numerical Simulation of Scouring Around Bridge Piers" World Academy of Science, Engineering and Technology. Vol. 58 pp. 1028-1032, 2009.
[5] Pakistan Engineering Services, Detail Engineering Design of Golen Gol Hydropower Project. A Report by PES. Lahore, 2008.

[6] N.R.B Olsen, "A three dimensional numerical model for simulation of sediment movements in water intakes with Multiblock Option”, User's Manual. 2006.

[7] T.S.Y. Paulos, and T. Ketema. "Evaluation of the sand trap structures of the Wonji-Shoa sugar estate irrigation scheme, Ethiopia.” Irrigation and Drainage Systems. Vol. 20, pp. 193-204, 2006.

\section{Creative Commons Attribution License 4.0 (Attribution 4.0 International, CC BY 4.0)}

This article is published under the terms of the Creative Commons Attribution License 4.0

https://creativecommons.org/licenses/by/4.0/deed.en US 